\title{
Protein kinase D2: a versatile player in cancer biology
}

\author{
Ninel Azoitei ${ }^{1} \cdot$ Mathias Cobbaut ${ }^{2} \cdot$ Alexander Becher $^{1} \cdot$ Johan Van Lint $^{2} \cdot$ Thomas Seufferlein $^{1}$
}

Received: 9 August 2017 / Revised: 14 September 2017 / Accepted: 15 September 2017

(c) Macmillan Publishers Limited, part of Springer Nature 2017

\begin{abstract}
Protein kinase D2 (PKD2) is a serine/threonine kinase that belongs to the PKD family of calcium-calmodulin kinases, which comprises three isoforms: PKD1, PKD2, and PKD3. PKD2 is activated by many stimuli including growth factors, phorbol esters, and G-protein-coupled receptor agonists. PKD2 participation to uncontrolled growth, survival, neovascularization, metastasis, and invasion has been documented in various tumor types including pancreatic, colorectal, gastric, hepatic, lung, prostate, and breast cancer, as well as glioma multiforme and leukemia. This review discusses the versatile functions of PKD2 from the perspective of cancer hallmarks as described by Hanahan and Weinberg. The PKD2 status, signaling pathways affected in different tumor types and the molecular mechanisms that lead to tumorigenesis and tumor progression are presented. The latest developments of small-molecule inhibitors selective for PKD/ PKD2, as well as the need for further chemotherapies that prevent, slow down, or eliminate tumors are also discussed in this review.
\end{abstract}

\section{Introduction}

Protein kinases comprise a gene family of 538 members in the human genome [1] and have been involved in a multitude of complex cellular functions and pathways. Despite their diverse functions, protein kinases adopt a strikingly similar active conformation of the catalytic domain $[2,3]$ catalyzing the transfer of the $\gamma$-phosphate of adenosine 5'-triphosphate (ATP) to the substrate's hydroxyl group of either serine, threonine, or tyrosine residues through a process called phosphorylation. Protein phosphorylation regulates most aspects of cell life [4] and deregulation of this process via dysfunctional kinase activity has crystallized as a major mechanism by which tumor cells escape normal physiological constraints on survival and growth [5]. Protein kinase D (PKD) family comprises three highly conserved enzymes in humans: PKD1, PKD2, and PKD3. The evolution of these isoforms appears to be associated with the evolution of vertebrates. Although only two PKD

Ninel Azoitei

ninel.azoitei@uni-ulm.de

1 Center for Internal Medicine I, University of Ulm, Ulm, Germany

2 Laboratory for Protein Phosphorylation and Proteomics, Department of Cellular and Molecular Medicine, Leuven Cancer Institute, KU Leuven, Leuven, Belgium members are expressed in fish, amphibians, and birds, all three PKD isoforms are expressed in mammals. PKD isoform found in amphibians and fish most closely resembles mammalian PKD1, whereas the invertebrate PKD found in Drosophila is most closely homologous with PKD3. By contrast, PKD2 seems to have evolved from mammals onwards [6]. PKD1 and PKD2 are the most closely related of the three mammalian PKD isoforms and share similar regulatory molecular mechanisms in various cell types. Members of the PKD family are effectors of diacylglycerol (DAG) signaling and are (often) activated downstream of protein kinase $\mathrm{C}$ by multiple stimuli including growth factors and hormones. They are implicated in various functions, both physiological and pathological, such as cell viability and proliferation, growth and differentiation, intracellular trafficking and regulation of the Golgi complex. Several reports described an essential role of PKD isoforms in carcinogenesis and tumor progression. Importantly, PKD members can display tissue-dependent expression and perform isoform-specific functions in different contexts. So far, many studies of PKD function do not specify the PKD isoform studied. Since molecular cloning and first characterization of human PKD2 in our laboratory 16 years ago, a compelling body of evidence on the role of this kinase in tumorigenesis and cancer progression has accumulated. The current review aims to summarize, integrate, and present most of these findings under the aspects of the basic principles in cancer biology. 


\section{Protein structure and regulation}

PKD was cloned and characterized in the mid of 1990s [7, 8]. Due to the presence of two phorbol ester and DAG C1-binding domains, PKD was initially regarded by one group as a member of protein kinase $\mathrm{C}$ family and termed $\mathrm{PKC} \mu$. $\mathrm{PKC} \mu$ was included in the group of the atypical protein kinase $\mathrm{C}$ (aPKC: $\xi$ and 1 ) that together with the classical protein kinase $\mathrm{C}$ (PKC) members (PKCs: $\alpha, \beta 1, \beta 2$, and $\gamma$ ) and the novel PKCs isoforms (nPKCs: $\delta, \eta, \varepsilon$, and $\phi$ ) form a superfamily of serine/threonine kinases implicated in the regulation of growth, differentiation, transformation, and apoptosis. However, careful examination of the catalytic domain of $\mathrm{PKD} / \mathrm{PKC} \mu$ revealed that the kinase domains show little similarity to the highly conserved regions of the kinase subdomains of the PKC family but are rather related to the $\mathrm{Ca}^{2+} /$ calmodulindependent protein kinase II-like protein kinases [1]. Furthermore, the substrate specificity of $\mathrm{PKD} / \mathrm{PKC} \mu[7,9]$ and its sensitivity to inhibitors [8] are unlike those of the PKC family. Therefore, the members of the PKD family were considered as a distinct family of protein kinases belonging to the $\mathrm{Ca}^{2+-}$ /calmodulin-dependent protein kinase (CAMK) group, later named PKD1. The PKD family also included two other isoforms, PKD2 [10] and PKD3 (PKCv) [11, 12]. All three isoforms of this kinase family share similar structural features such as the highly conserved N-terminal regulatory domain containing two cysteine-rich DAG-binding $\mathrm{C} 1$ domains and an auto-inhibitory pleckstrin homology (PH) domain (Fig. 1). Interestingly, PKD1 and PKD2 share $\sim 85 \%$ overall identity at the amino-acid level and display an even higher degree of homology in their catalytic domain and $\mathrm{C} 1$ domains, which represent the key for controlling the intracellular localization of these kinases. The $\mathrm{C} 1$ domains are also thought to be involved in the regulation of PKD activity. Interestingly, however, although deletion of the $\mathrm{C} 1$ domains in PKD1 results in elevated kinase activity, similar deletions in PKD2 abrogate its activity. The N-terminal regulatory domain also contains a pleckstrin homology domain involved in auto-inhibition. Partial deletions or a full ablation of the $\mathrm{PH}$ domain results in increased kinase activity $[13,14]$. The PKD2 mRNA is widely expressed and encodes an 878-amino-acid protein of $105 \mathrm{kDa}$. $\mathrm{C} 1 \mathrm{a} / \mathrm{C} 1 \mathrm{~b}$ domain plays a complex role in the regulation of nucleocytoplasmic shuttling [15]. PKDs are regulated by phosphorylation. For PKD2, several phosphorylation sites have been identified including Ser706 and Ser710-in the activation loop corresponding to Ser744 and Ser748 in PKD1 [16] and an autophosphorylation site at Ser876, corresponding to Ser916 in PKD1 [10]. The latter phosphorylation site is not present in PKD3 (Fig. 1). PKD2 is also phosphorylated at Ser244 by casein kinase 1, which results in nuclear import [17]. Furthermore, PKD2 is also shown to be regulated via the phosphorylation of several tyrosine residues. For example, PKD2 is phosphorylated at Tyr717 in the $\mathrm{P}+1$ loop by $\mathrm{Abl}$ in oxidative stress conditions in an isoform-specific manner, which results in increased kinase activity [18]. Tyr87 phosphorylation has also been shown in oxidative stress conditions and was thought to be necessary for PKCS-mediated PKD2 activation in oxidative stress conditions, but recent data suggest that this event might be superfluous to this extent. Canonical activation of PKD is induced by PKC through the phosphorylation of Ser706/710 in the activation loop [19]. As for PKD1, PKD2 becomes activated downstream of Gprotein-coupled receptors through the activation of PLC $\gamma$, which in turn activates $\mathrm{PKC} \alpha, \mathrm{PKC} \varepsilon$, or $\mathrm{PKC} \eta[16]$. PKD2 can also be activated by gastrin via the cholecystokinin $\mathrm{B}$ receptor [16, 20], hypoxia [21], and by insulin-like growth factor (IGF)-1 [22].

\section{Protein expression and function}

In contrast to PKD1, a high steady-state expression level of PKD2 was demonstrated in human pancreas, lung, heart, smooth muscle, and brain $[8,10]$, whereas kidney and liver display lower levels of PKD2 mRNA. This suggests that various members of PKD family exhibit tissue-specific expression. In fast proliferating tissues, such as testis and colonic crypts, an augmented expression of PKD2 was

Fig. 1 Molecular architecture of protein kinase D family members: PKD1/PKC $\mu$, PKD2, and $\mathrm{PKD} 3 / \mathrm{PKC} \nu$. Adapted from Rykx et al. [12]

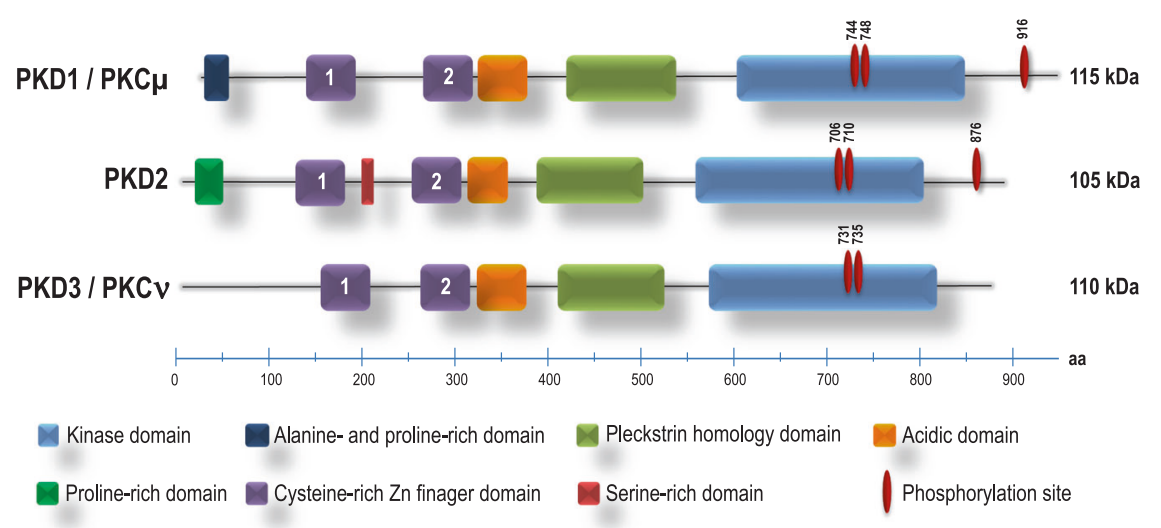


detected [10]. Additionally, mouse PKD2 but not PKD1, was specifically expressed in T-and B-lymphocytes that comprise the thymus, spleen, and lymph nodes [6]. As PKD1 and PKD2 have a similar (but not identical) molecular weight and are recognized by the same C-terminal antibodies, many older studies of PKD function did not specify which PKD isoform was investigated. Various adult tissues and cell lines show that different PKD isoforms are in some instances functionally redundant. For example, multiple PKD isoforms appear to regulate Golgi organization [23], protein transport [23-26], nuclear factor-kappa B (NF- $\kappa \mathrm{B})$-dependent cell survival response [13, 27, 28], and release of chemokines by Toll-like receptor-activated epithelial cells [29]. However, there are examples of cells/tissues where expression of a single PKD isoform appears to be predominant suggesting a specific and non-redundant role of a particular member of PKD family. Such an example is the role of PKD1 in regulating insulin secretion in pancreatic $\beta$-cells [30]. The observation of distinct PKD pools at different intracellular sites, including Golgi, cytoplasm, nucleus, mitochondria, and plasma membrane [31] further complicates our understanding of the functions of different PKD isoforms. In addition, various PKD isoforms can differently localize within the same cell [31, 32] or shuttle between cytosol and nucleus in response to particular stimuli $[33,34]$. Several reports imply PKDs in the organization of the Golgi apparatus, regulating the fission of vesicles from the trans-Golgi network (TGN) [23, 35]. PKD phosphorylates several substrates at the Golgi, including PI4KIII $\beta$ [36], ceramide transferring protein (CERT) [37], and oxysterol-binding protein 1 (OSBP1) [38]. Phosphorylation of PI4KIII $\beta$ results in increased production of phosphatidylinositol-4-phosphate (PI(4)P), which serves as a lipid "platform" to recruit lipidmodifying enzymes and other regulating factors including CERT and OSBP [36-38]. PKD-mediated phosphorylation of CERT and OSBP1 results in decreased affinity for PI(4)P, making PKD an important sensor and mediator of lipid homeostasis at the TGN $[37,38]$. Vesicle budding by PKD is thought to occur through its $\mathrm{Cla}$ domain mediated binding of DAG at the outer leaflet of the TGN, followed by the recruitment of phospholipase D (PLD) into the ARF1-PKD complex. PLD generates phosphatidic acid (PA) from PtdCho, which can be further converted into Lyso-PA (LPA). LPA can form spontaneous curvatures, promoting vesicle budding [38]. Very recently our lab revealed that PKD2 and not PKD1, is a core factor in the assembly of a functional multiprotein complex at the TGN that regulates matrix metalloproteinase 2 (MMP2) secretion [39]. Importantly, these processes require direct binding of PKD2 to ARF1 GTP-ase.

Many initial studies of PKD function did not specify which PKD isoform was being referred to when role of the kinase in the immune system was investigated. For instance, Sidorenko and colleagues referred to PKD when they first revealed that $\mathrm{T}$-cell receptor (TCR) cross-linking causes activation of kinase [40]. Furthermore, PKD was described to regulate different aspects of T-cell differentiation and development of mature T-lymphocytes [40]. More knowledge about the function of PKD isoforms in immune system comes from Cantrell's group [6, 41]. Using PKD2 and PKD1 transgenic mice and PKD2 gene-trap mutant mice, this study demonstrates that $\mathrm{T}$ - and B-lymphocytes specifically express PKD2, but not PKD1 [6, 41]. Furthermore, the catalytic activity of PKD2 is important for optimal Tcell-dependent antibody response in vivo and effective cytokine production after TCR engagement. In this context, PKD2 kinase dead mutant T-lymphocytes fail to produce interleukin-2 (IL-2) and interferon- $\gamma$ (IFN $\gamma$ ) that are critical for the adaptive immune response, a fact that suggests a role of the kinase in controlling cytokine production [41]. PKD1 and PKD2 display similar subcellular trafficking and activation kinetics in response to antigen receptor in A20 lymphoma B cells and leukemic Jurkat T-cell line [41-43]. Altogether, this study provides evidence that PKD2 has, at least in some settings, a unique non-redundant role in controlling T-cell function during adaptive immune response and urges for further detailed investigations.

PKDs are also involved in vasculogenesis and myogenic differentiation. Formation of vasculature involves the assembly of endothelial cells into tubes that takes place during embryogenesis [44]. In addition, members of PKD family were reported to be involved in cardiac, skeletal, and smooth muscle regulatory processes such as the mediation of the hypertrophic response to angiotensin II or stimulation of myocyte enhancer factor-2 (MEF2) activity in skeletal muscle thus playing a crucial role in heart remodeling [4549]. Our lab examined the putative participation of PKDs to myogenic differentiation by involving murine $\mathrm{C} 2 \mathrm{C} 12$ myoblasts [50]. $\mathrm{C} 2 \mathrm{C} 12$ differentiate rapidly and represent a bona fide in vitro model to study the differentiation of myoblasts to myotubes. Although both PKD2 and PKD3 are predominantly expressed in $\mathrm{C} 2 \mathrm{C} 12$ cells, only PKD2 was found to be catalytically active during the early phase of differentiation to skeletal muscle cells [50]. Selective depletion of PKD2 was sufficient to prevent differentiation of $\mathrm{C} 2 \mathrm{C} 12$ cells [50]. By contrast, ectopic expression of the kinase augments the initiation of myoblast differentiation by activating Mef2D, a transcription activator that specifically binds to the MEF2 element present in regulatory regions of many muscle-specific genes that control cardiac morphogenesis and myogenesis [49].

\section{The role of PKD2 in cancer}

Cancer development is a complex process characterized by various epigenetic and genetic modifications that promote resistance to pro-apoptotic stimuli and confer insensitivity 


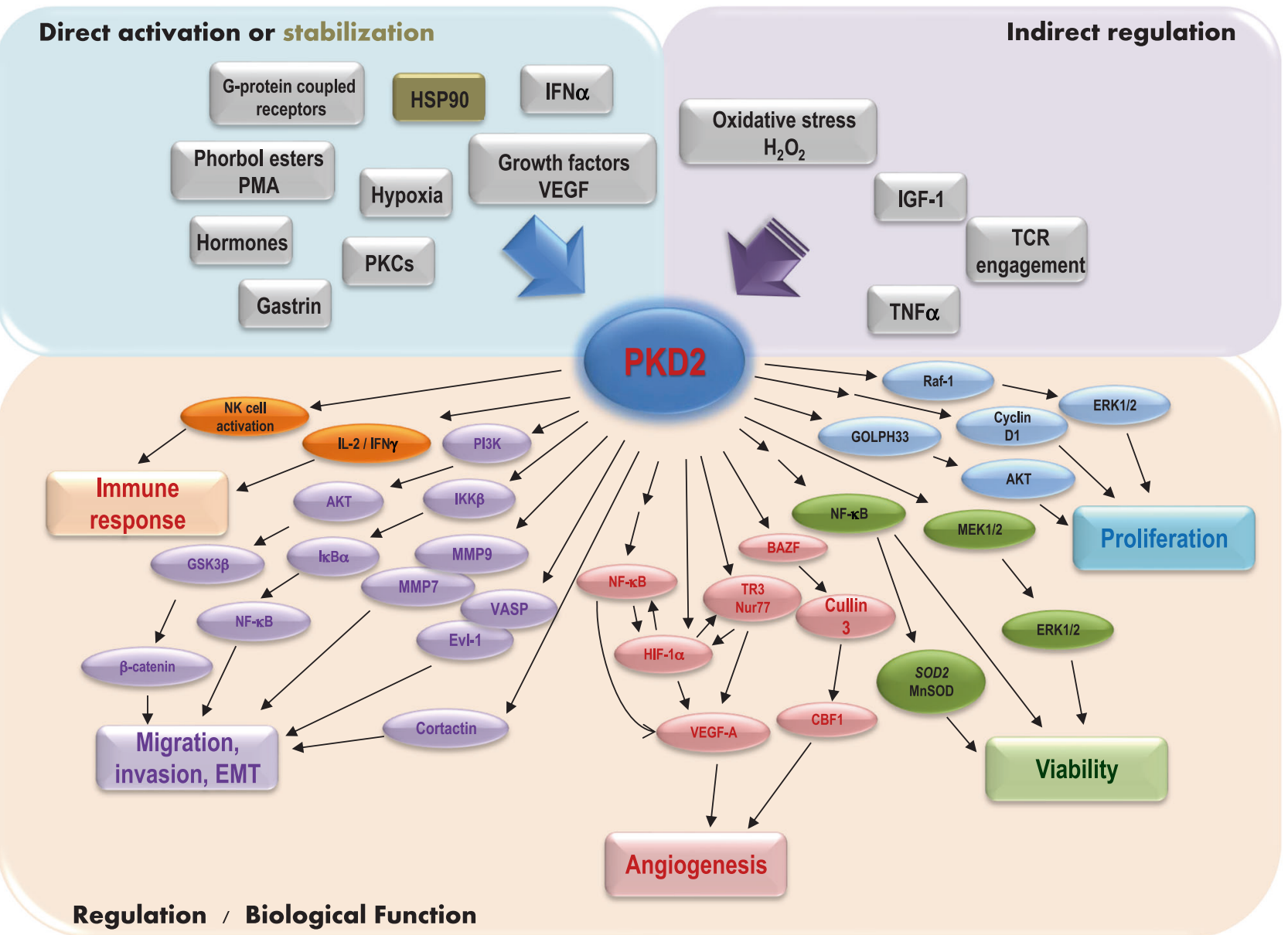

Fig. 2 PKD2 is involved in the regulation of multiple signaling pathways, as well as in the integration of extracellular signals. Separate circuits present the capability of PKD2 to orchestrate cancer cell proliferation (blue), survival (green), angiogenesis (red), motility (violet), and immune response (orange). This depiction is rather simplistic, as there is considerable crosstalk between signaling pathways

to antigrowth signals while sustaining angiogenesis and immune surveillance. At the beginning of this millennium, Hanahan and Weinberg defined six hallmarks of cancer as distinctive and complementary capabilities that enable tumor growth and metastatic dissemination [51]. Cancer cells are able to sustain proliferative signaling, evade tumor suppressors, capable of invasion and metastasis, resist apoptosis, promote angiogenesis, and enable replicative immortality [51]. The conceptual progress made since the year 2000 enabled not only describing new features crucial to the six hallmark capabilities but also the acquisition of novel hallmarks such as deregulation of the cellular metabolism and avoiding immune destruction [52]. Furthermore, the progress in technology and knowledge in cancer research revealed, solidified, and extended the concept of cancer biology in the sense that various factors such as the tumor microenvironment have to be taken into account and comprising of $\mathrm{PKD} 2$-regulated molecules that participate to more than one cancer hallmark (e.g., NF-кB). Furthermore, due to the fact that each cancer cell is exposed to a variety of signals from its microenvironment, each of these signaling pathways is connected to direct (light blue) or indirect (light violet) signals originating from other cells in the tumor microenvironment

that cancer is not defined by simply enumerating various traits of tumor cells [52]. The heterogeneity in tumor microenvironment, such as for instance the availability of oxygen in different sections of a tumor, often leads to heterogeneity in the expression profiles of cancer cells within that particular tumor. The variation in the expression signatures in different regions of a tumor translates to a perturbation of regulatory signaling pathways, which makes difficult to find a suitable therapy for the whole tumor. The disruption of regulatory pathways in cancer cells is often a source for genomic instability. Prime examples of deregulated molecules are kinases [53], which have become the most intensively pursued anticancer drug targets. Furthermore, kinases are placed at the crossroad/junction of multiple signaling pathways in the intricate intracellular molecular circuitry governing cancer cell biology (Fig. 2). Various kinases, including PKD2, show elevated protein 
levels in tumors and might serve as cancer biomarkers. Particularly high PKD2 expression was revealed in multiple epithelial tumors, including pancreatic [21, 54, 55], colorectal $[21,56]$, prostate [57, 58], gastric [21, 59], breast cancer [60, 61], and hepatocellular carcinoma [62]. High expression of the kinase was also detected in glioblastoma multiforme [63-65] and myeloid leukemia [27]. In the following, we will highlight the most important functions of PKD2/PKD from the perspective of cancer hallmarks as described by Hanahan and Weinberg [51, 52]. As an add-on to these, newly described, as well as potential functions of PKD2 are also presented.

\section{Sustaining proliferative signaling}

Normal tissues tightly regulate the production and secretion of growth-promoting signals thereby ensuring the homeostasis and the maintenance of normal tissue architecture and function. By contrast, tumor cells not only deregulate such signals, but also enable signaling mechanisms conveyed largely by growth factors that control the progression through the cell cycle, proliferation, and cell growth. For instance, activation of the extracellular-signal regulated kinase (ERK) pathway culminates with the transactivation of various transcription factors implicated in growth, differentiation, or mitosis. PKD has been shown to prolong ERK signaling via phosphorylation of Ras and Rab interactor 1 at Ser351 [66]. This induces 14-3-3 binding and results in cytoplasmatic sequestration of this interactor, which in turn potentiates the interaction between Ras and the RAF kinase, potentiating ERK signaling [66]. Furthermore, although no direct evidence is present, a putative participation of PKDs to PKC-mediated mitogen-activated protein kinase (MAPK) signaling toward cell proliferation should be also taken into account. Recent evidence suggests that PKDs may play a role in colon cancer. PKD2 is the major isoform in human colon cancer cells, whereas PKD1 is not expressed [67]. Inhibition of PKD with CRT0066101 had anti-proliferative effects on colon cancer cell lines and on tumor growth in a HCT-116 xenograft model. Mechanistically, effects were seen on AKT and ERK signaling after inhibition or knockdown of PKD2 (but not PKD3) [67]. A link between growth factor signaling and cell cycle progression is provided by cyclin D1, which is induced as a secondary response following mitogenic stimulation. Recently, we showed that PKD2 abrogation in glioblastoma cells induced the arrest of tumor cells in the G1 phase of cell cycle, an event that was associated with downregulation of cyclin D1 [63]. Moreover, abrogation (both pharmacologic and genetic) of PKD2 prevented formation of glioblastoma tumors in vivo and corresponded to a significantly reduced number of Ki67-positive tumor cells [63]. Bernhart and colleagues extended these findings to a xenograft mouse model using CRT0066101, a PKD family inhibitor [64]. PKD2 silencing was associated with glioma cell senescence via p53-dependent and -independent pathways [65]. Interestingly, although PKD2 overexpression resulted in enhanced proliferation and migration of gastric cancer cells, ectopic PKD1 had the opposite effects, suggesting that expression level of PKD1/PKD2 may differentially determine the behavior of gastric tumor cells. In a similar manner, silencing of PKD2 but not of PKD1 significantly inhibited the proliferation of primary human endothelial cells [68]. In addition, our lab could demonstrate that PKD2 knockdown in pancreatic cancer cells orthotopically implanted in mouse pancreas was associated with impaired tumor growth [21], further substantiating a pro-proliferative role of PKD2. Ectopic PKD2 expression correlated with augmented expression of Golgi phosphoprotein 3 (GOLPH3) [69], a membrane protein located at the TGN that is involved in vesicle transportation from Golgi to the cell membrane and in the glycosylation of proteins. In this study, high level of GOLPH3 was associated with the activation of phosphoinositide 3-kinase (PI3K)-AKT and enhanced glioma proliferation [69]. Furthermore, GOLPH3 was demonstrated to be a novel oncogene, which is commonly targeted for amplification in human cancers and regulates the response to rapamycin [70]. Growth factors such as gastrin or IGF-1 stimulate PKD activity in addition to their role in tumor cell growth [71-73]. In addition, vascular endothelial growth factor (VEGF) A-mediated PKD activation in endothelial cells was reported to promote both proliferation and migration $[74,75]$. Many of these events involve PKC-mediated PKD phosphorylation [17].

\section{Resistance to cell death}

Programmed cell death (apoptosis) serves as a natural barrier to cancer development $[52,76,77]$. PKD1 was reported to promote cell survival through the induction of antiapoptotic proteins survivin and cellular FLICE (FADD-like IL-1 $\beta$-converting enzyme)-inhibitory protein long form (c-FLIPL) in pancreatic cancer cells [78]. PKD1 and PKD2 protect cells from oxidative stress-induced cell death by activating the transcription factor NF- $\mathrm{KB}[13,28,79$, 80]. Interestingly, recent evidence suggests isoform-specific regulation of PKDs in oxidative stress conditions, which is paired by differential requirements for their signaling output to NF- $\mathrm{BB}$. Indeed, PKD2 signaling to NF- $\mathrm{BB}$ requires phosphorylation of the kinase at Tyr438 in the human myeloid leukemia cells [27]. However, in contrast to PKD1, activation of NF- $\mathrm{\kappa B}$ by PKD2 tyrosine phosphorylation is independent of its catalytic activity. This may suggest that PKD2 acts rather as a chaperone or scaffold and not as a kinase in this process [27]. The production of reactive 
oxygen species (ROS) at the mitochondria, an event intimately associated with a variety of human diseases [81-83], has been demonstrated to initiate a mitochondria-to-nucleus signaling cascade in which PKD plays a critical function [80]. In this scenario, elevated mitochondrial ROS (mROS) production results in PKD-dependent activation of NF-KB. Translocation of NF- $\mathrm{kB}$ to the nucleus followed by induction of SOD2 leads to subsequent expression and accumulation of manganese superoxide dismutase (MnSOD), detoxification of ROS, and finally increased cellular survival $[13,80]$. Together with other stimuli, ROS also induces apoptosis signal-regulating kinase 1 (ASK1), an upstream activator of c-Jun N-terminal kinase (JNK) and p38 signaling cascades [84]. Using kinase inhibitors and RNA interference, Zhang and colleagues identified PKD1 as $\mathrm{s}$ critical upstream mediator in $\mathrm{H}_{2} \mathrm{O}_{2}$-induced ASK1 activation and showed that 14-3-3 binding to PKD1 plays a critical role in mediating $\mathrm{H}_{2} \mathrm{O}_{2}$-induced ASK1-JNK activation and endothelial cell apoptosis [85]. PKD1 can also activate JNK downstream of death-associated protein kinase (DAPK) (in a PKC-independent fashion), which results in a pro-death signal and increased necrotic cell death [86]. Furthermore, Chen and colleagues demonstrated a prosurvival and anti-apoptotic role of PKD2 in phorbol myristate acetate (PMA)-induced apoptosis in androgensensitive model of human prostatic carcinoma (LNCaP) prostate cancer cells and identified ERK1/2 and NF- $\mathrm{KB}$ as downstream effectors [87]. In this study, the authors suggest that PKD2 may signal through non-redundant pathways to modulate PMA-induced apoptosis. Recently, we found that HSP90 chaperone interacts with and stabilizes PKD2 in human cancer cells. Depletion of PKD2 following HSP90 inhibition was corroborated with tumor cell death in vitro, as well as in vivo xenograft models [88]. Implication of the kinase in cell death evoked by HSP90 inhibition together with its ability to mediate stress-induced NF- $\mathrm{KB}$ activation and cell survival [13] infer that PKD2 represents an essential molecule involved in HSP90 signaling down to $\mathrm{NF}-\mathrm{\kappa B}$ and is associated with chaperone-supported cancer cell viability.

\section{Role in EMT}

Prior to intravasation, cancer cells often undergo the process of epithelial-to-mesenchymal transition (EMT), an event by which epithelial cells lose their polarization by reorganizing their cytoskeleton and undergoing distinct biochemical changes that allow transition to mesenchymal cells capable to invade, resist apoptosis, and disseminate [89-91]. Although PKD1 was reported to inhibit EMT by controlling the localization of the transcription factor Snail $[92,93]$ and through E-cadherin phosphorylation [94, 95], the role of PKD2 or PKD3 in the regulation of EMT is poorly understood. Indirect evidence indicates that these two isoforms are potential positive regulators of EMT. Treatment of MDA-MB-231 breast cancer cells with the selective panPKD inhibitor CRT0066101 led to reduced expression of EMT markers such as Snail, N-cadherin, MMP9, smooth muscle actin (SMA), and vimentin [96]. Indeed, these data are in line with our own findings showing that ectopic expression of PKD2 in MDA-MB-231 breast or A549 lung cancer cells correlates with acquisition of a mesenchymal phenotype, loss of E-cadherin, and gain of vimentin expression (Azoitei and Seufferlein, unpublished data). Tumor necrosis factor (TNF) $\alpha$ plays an important role in EMT in many cancer cells [97, 98] but also triggers the association of TNFR1 and TRAF2, an event that is required for PKD2 activation and EMT [62]. PKD2 was demonstrated to contribute to TNF $\alpha$-induced EMT and invasion by increasing the activity of the PI3K/AKT/glycogen synthase kinase 3 beta $($ GSK-3 $\beta) / \beta$-catenin pathway [62]. Phosphorylation of GSK-3 $\beta$ by PKD2 was followed by translocation of $\beta$-catenin to the nucleus, regulation of T-cell factor/lymphoid enhancer factor (TCF/LEF)-dependent transcription and enhanced EMT and invasiveness in hepatocellular carcinoma [62].

\section{Invasion and metastasis}

The multistep nature of invasion and metastasis has been schematized as a succession of changes in cell biology, beginning with local invasion that leads to intravasation of cancer cells into proximal blood or lymphatic vessels. The journey of cells with the blood/lymph stream to remote distances is followed by the movement of cancer cells from the vessel lumen into the parenchyma of remote tissues (extravasation), establishment of small nodules of cancer cells (micrometastasis), and finally the growth of micrometastatic lesions to macroscopic tumors [51, 52]. PKD1 and PKD2 isoforms show similar structural features and fulfill a variety of overlapping functions [12, 99]. However, their expression in various tumors is not identical. This leads to the fact that tumor-relevant parameters are controlled in an isoform-specific manner, sometimes even in an opposing manner. For instance, PKD1 is downregulated in invasive breast cancer cell lines suggesting an inhibitory role of tumor cell motility [100-102]. The inhibition of tumor cell motility by ectopic PKD1 was also demonstrated in other tumor cells including pancreatic cancer cells. Our lab has investigated the direct cell motility in a pancreatic ductal adenocarcinoma (PDAC) model system and compared the PKD1 and PKD2 invasive features in threedimensional extracellular matrix (ECM) culture [55, 103]. In this study, PKD1-regulated migration by interacting with cofilin-phosphatase Slingshot-1L (SSH1L) at the cell periphery and in dynamic membrane protrusions [55, 103]. 
However, although on the one hand PKD1 stable knockdown strongly enhanced invasive outgrowth from tumor clusters, ectopic expression of PKD2 on the other hand significantly enhanced invasion of pancreatic cancer cells in the surrounding the ECM [55, 103]. This is in line with another study showing that abrogation of PKD2 in doxorubicin-resistant Michigan Cancer Foundation-7 (MCF-7) breast cancer cells led to a significant reduction in cell migration [61]. ECM and cancer cells display an intimate interaction. Thus, ECM can influence the behavior of cancer cells, which in turn can cause breakdown of basal membranes by enhanced secretion of MMPs [104]. We identified in pancreatic cancer cells a novel isoform-specific regulatory function for PKD2 upstream of MMP7 and MMP9 in promoting invasion and angiogenesis both in vitro and in vivo [55, 103]. Interestingly, MMP9 is responsible for the release of VEGF [96, 104, 105], a growth factor essential in tumor angiogenesis of whose regulation by PKD2 will be discussed in more detail in the angiogenesis section. The events of invasion and migration promoted by PKD2-regulated MMPs and integrin expression were also reported in glioblastoma [64] and stromal myofibroblasts [106]. Interestingly, in contrast to the effects of PKD2 on MMPs, PKD1 expression in osteosarcoma cells has been shown to reduce invasiveness likely via the decrease of MMP2 expression in these cells. PKD2 and PKD3 also regulate migration and invasion via other mechanisms. For example, in prostate cancer cells, PKD2 interacts with and phosphorylates inhibitor of nuclear factor kappa-B kinase subunit beta (IKK $\beta$ ) while is responsible for inhibitory kappa B protein alpha (IאB $\alpha$ ) degradation [58]. The fact that subsequent nuclear translocation of p65 was primarily dependent on PKD2 rather than PKD3, suggests that PKD2 may play a role in classical NF- $\mathrm{\kappa B}$-mediated cell invasion [58]. In addition, PKD2 also promotes invasion and tumor cell migration by phosphorylating the splice variant of calcium and integrin-binding protein 1 (CIB1a) [107]. Several studies revealed additional substrates for PKDs at the leading edge such as Ena/VASP-like protein (EVL)-1 [108], vasodilator-stimulated phosphoprotein (VASP) [109], and cortactin [110].

\section{Induction of angiogenesis}

In order to grow, tumors require oxygen and nutrients, as well as the possibility to evacuate metabolic wastes and $\mathrm{CO}_{2}$. Angiogenesis, the generation of tumor-associated neovasculature from pre-existing vessels, is the process that ensures all these needs. A large body of evidence demonstrates that the angiogenic switch is orchestrated by countervailing factors that either oppose or induce angiogenesis [111]. A well-known inducer of angiogenesis is VEGF-A, which governs the growth of new blood vessels both in physiological and pathological conditions [112]. VEGF gene expression can be regulated both by hypoxia and by oncogene signaling $[113,114]$. Many epithelial tumors are characterized by their ability to grow in hypoxic environment [115-117]. This usually requires upregulation of hypoxia inducible factor 1-alpha (HIF-1 $\alpha$ ), a transcription factor involved in the cellular response to hypoxia. Hypoxia-mediated VEGF-A expression can be mediated by molecular mechanisms dependent on PKCs [118]. Indeed, our experiments revealed a marked increase in PKD activation under hypoxic conditions [21]. Our lab and others have previously shown that PKD2 modulates the expression of the orphan-nuclear receptor TR3/Nur77, a protein that has been reported to be a stabilizer of HIF- $1 \alpha$ and mediator of VEGF expression [21, 119, 120]. Later experiments demonstrated that hypoxia-induced VEGF-A expression and secretion requires expression of TR3 in pancreatic cancer cells, which in turn crucially requires PKD2 [21]. Furthermore, mere abrogation of PKD2 in the tumor cells prevented tumor angiogenesis in two in vivo experimental models, chicken CAM and orthotopic pancreatic tumor xenograft in nude mice [21]. Interestingly, PKD2 is highly expressed not only in tumor cells but also in endothelial cells [21]. Treatment of mice with Vivo-Morpholino spliceblocking oligonucleotides targeting murine PKD2 resulted in impaired blood vessel formation, which resulted in the formation of smaller tumors [21]. Similarly, depletion of PKD2 resulted in decreased basal and VEGF-A-induced endothelial cell sprouting [21]. These data are in line with the fact that PKD2, but not PKD1, is expressed in primary human endothelial cells from various tissues and is required for the expression of VEGFR-2 in endothelial cells [68]. Moreover, in endothelial cells PKD2 is activated by VEGF via tyrosine phosphorylation $[74,75]$ and contributes to endothelial cell proliferation, migration, and angiogenesis in vitro [68]. A recent study identified PKD2 as a crucial molecule in the stabilization of BCL6-associated zinc-finger (BAZF) protein upon induction by VEGF-A [121]. VEGFA-induced BAZF forms a complex with cullin 3, an E3 ubiquitin ligase that degrades CBF-1, a transcription factor implicated in Notch signaling [122, 123]. To note, angiogenic sprouting is tightly regulated by the Notch signaling circuit of the VEGFR-Notch ligand, Dl14 [123-125]. Interestingly, HSP90 inhibitors 17-AAG and PU-H71 inhibited PKD2-mediated stabilization of BAZF-mRNA [126, 127]. This is in line with our experiments demonstrating that the HSP90 chaperone supports tumor growth and angiogenesis through PKD2 protein stabilization [88]. In this study, we have identified PKD2 as a novel client of the chaperone and demonstrated that ectopic expression of PKD2 restored tumor cell viability and vascularization after HSP90 pharmacologic inhibition in vivo. These results support PKD2 degradation through HSP90 inhibition as a potential 
strategy to approach two important cancer features, angiogenesis, and cell viability, with one drug. HSP90 inhibitors have been reported to indirectly regulate HIF-1 $\alpha$ [126-128]. The fact that the chaperone interacts both with HIF-1 $\alpha$ [128] and PKD2 [88] likely implicates PKD2 in tumor angiogenesis coordinated by HSP90/HIF- $1 \alpha$. Indeed, ectopically expressed PKD2 partially restores HIF- $1 \alpha$ protein levels, HIF-1 $\alpha$ transcriptional activity, and secreted VEGF-A levels after HSP90 inhibition [88]. Although Choi and colleagues demonstrated that TR3/Nur77 is activated by HIF-1 $\alpha$ [129], in the same year Yoo et al. revealed that TR3/Nur77 stabilizes HIF-1 $\alpha$ [130]. It still remains to be elucidated whether PKD2 restores HIF-1 $\alpha$ through the induction of TR3/Nur77 or whether PKD2 activates TR3/ VEGF-A by stabilizing HIF- $1 \alpha$. As the transcription factor $\mathrm{NF}-\kappa \mathrm{B}$ and its target gene $V E G F-A$ are activated by hypoxia, HSP90, and PKD2 [88, 131], it is possible that NF- $\kappa \mathrm{B}$ signaling might be connected to the hypoxic response governed by HSP90-PKD2. However, in this study PKD2 only marginally restored hypoxia-induced NF$\kappa \mathrm{B}$ promoter activity during chaperone inhibition, suggesting that additional factors/clients are necessary to transmit HSP90's angiogenic signals via NF-kB pathway [88]. Whether PKD2 activates NF- $\mathrm{KB} / \mathrm{VEGF}-\mathrm{A}$ via upregulation of HIF- $1 \alpha$ or whether interaction with other molecules is required (such as IKK [89]) is not fully understood so far. Furthermore, our lab has identified a novel splice variant of CIB1a as a potential substrate of PKD2 [107]. PKD2 interacts with and phosphorylates CIB1a at Ser115, which is associated with tumor cell growth and angiogenesis [107]. Another process through which PKD2 controls tumor angiogenesis is secretion of MMPs. Although PKD2 controls secretion of MMP7 and MMP9, only MMP9 was shown to augment the release of extracellular matrix-bound VEGF-A [107]. The fact that PKD2 controls angiogenesis via regulation of molecules such as CIB1a or MMPs, shown to promote also tumor cell invasion, indicates again the versatility and the implication of this kinase in different aspects of cancer biology.

\section{Regulation of innate and adaptive immune defenses}

Human and mouse T- and B-lymphocytes, thymocytes, and spleen cells predominantly express PKD2, but not PKD1 or PKD3 [6]. PKD2 catalytic activity is important for effective cytokine production after TCR stimulation. TCR stimulation results in the translocation of PKD2 to the nucleus, an event associated with the induction of IL- 2 and IFN $\gamma$ production, which play a critical role in adaptive immune responses. TCR engagement induces DAG production and activates PKCs [132-134], which were shown to phosphorylate Ser707 and Ser711 in PKD2. The failure of catalytically inactive PKD2 T-lymphocytes to effectively produce IL-2 and IFN $\gamma$ suggests that PKD2 has a unique role in controlling T-cell functions during adaptive immune responses [6]. IFN $\alpha$-stimulated activation of PKD2 requires its phosphorylation at Tyr438, a molecular event also necessary for efficient serine phosphorylation and degradation of IFNAR1 and consequently restriction of magnitude and duration of cellular responses to type 1 interferon including $\mathrm{IFN} \alpha / \beta$ [135]. As IFN $\alpha / \beta$ are used in treatment of infections, multiple sclerosis, and cancers, deciphering the mechanisms of ligand-inducible activation of PKD2 and its recruitment to the receptor may be of clinical relevance [135]. Notably, IFN $\alpha / \beta$ antagonizes the process of angiogenesis that is stimulated by VEGF, and both counteracting stimuli activate PKD2. VEGF-mediated recruitment of PKD2 to the IFNAR1 is followed by phosphorylation, ubiquitination, and degradation of the receptor subsequent to inhibition of type 1 IFN signaling. The fact that degradation of the IFN1R is required for efficient VEGF-stimulated angiogenesis [135] adds another level of complexity to the role of PKD2 in cancer progression. Interestingly, PKD2 was recently also implicated in a pathway that drives PDL-1 surface expression downstream of IFN- $\gamma$ in oral squamous carcinoma, which argues for the combination of (PKD) targeted therapies with the emerging immune therapies [136]. Several other studies revealed that PKD2 does not only play a role in adaptive but also in the innate immune responses. Natural killer (NK) cells were reported to establish the first line of defense against tumor and virus-infected cells [137, 138] and their activation is subdivided in two mechanisms: natural toxicity and CD16mediated antibody-dependent cellular toxicity. Engagement of CD16 was demonstrated to cause responses in various kinases including PKD2, indicating a role in the signal network orchestrating NK cell effector functions [139, 140]. In this study, application of CID755673, a selective inhibitor of PKD family members, resulted in a significant dosedependent reduction of NK cell degranulation markers and cytokine release. These data underline PKD2 as a signaling component in NK cell activation and therefore as a molecule with a potential role in cancer immunosurveillance.

\section{Regulation of protein transport and secretion}

Altered vesicular sorting or transport of specific proteins has been repeatedly linked to a broad range of cancer types and therefore represents a promising target for therapeutic interventions [141]. PKD isozymes are instrumental in the regulation of protein secretion from the TGN to the plasma membrane [142] by acting as key regulators of membrane fission of transport carriers at the TGN [25, 143-145]. All three isoforms of PKD have been implicated in secretory vesicle biogenesis $[17,26]$. In this context, a substantial function of PKD1 in the secretion of several tumorpromoting factors including IL-6, IL-8 and growth-related 
oncogene- $\alpha$ in endothelial cells and epithelial cancer cell lines has been characterized [146-148]. PKD2, on the other hand, has been shown to mediate constitutive secretion of MMPs (MMP7 and MMP9) [55], which have both been linked with overall survival in gastric cancer [149] and more generally in tumor metastasis. A vital function of PKD2 was also described in the regulation of peptide hormone release, namely of the neuroendocrine tumor marker chromogranin A, from carcinoid derived pancreatic cells [25]. Furthermore, the isoform PKD3 plays a critical role in the secretion of tumor-promoting factors, for example, in prostate cancer [150]. It is understood that the function of PKDs in vesicle formation is, at least partially, mediated by the phosphorylation and thereby activation of substrate proteins like phosphatidylinositol-4 kinase III $\beta$ and ceramide transfer protein CERT, followed by changes within the local lipid environment [151, 152]. It is known that PKDs are associated with the TGN by binding to DAG via their C1a zinc-finger domain. PKD2 directly interacts via Pro275 in its C1b domain with ARF1 [153], a GTPase that directly regulates the assembly of budding vesicles by recruiting coat (COPI) and clathrin adaptor proteins to the TGN and by activating lipid-modifying enzymes [154-159]. Mutation of P275 prevents PKD2 localization to the TGN, resulting in a severely reduced secretion of cargo proteins [153]. Interestingly, it was shown that PKD dimerization is essential for effective DAG dependent secretion of membraneous cargo [160]. Furthermore, a recent study has identified a protein complex at the TGN comprising PKD2, ARF1, and the Arf-like GTPase Arl1 [39]. PKD2 acts as a scaffold protein, anchoring the complex at the TGN and recruiting effector proteins like the BAR domain protein arfaptin 2, independent of its kinase function and vital for constitutive secretion processes such as the transport of MMPs [39].

\section{Potential regulation of energy metabolism}

The uncontrolled growth of tumors does not only involve deregulated cell proliferation but also adjustments in the energy metabolism. In the early stages of cancer development, tumor cells proliferate beyond the limit of diffusion and face hypoxia, a low oxygen environment reported to prevent energy production by oxidative phosphorylation [161]. The increasing demand for energy by fast proliferating tumor cells in hypoxic microenvironment triggers rapid metabolic reprograming [161-163]. Upon activation of HIF- $1 \alpha / \mathrm{HIF}-2 \alpha$ transcription factors or by Ras oncoproteins, cancer cells undergo a "metabolic switch" by using glycolysis to efficiently maintain cellular bioenergetics in restrictive growth conditions [162-165]. To date, there is no direct evidence on the role of PKD2 in the process of aerobic glycolysis. However, an indirect role of the kinase in energy metabolism could be envisaged upon regarding its involvement in the regulation of HIF- $1 \alpha$. Indeed, we demonstrated that abrogation of PKD2 in pancreatic cancer cells resulted in impaired hypoxiainduced HIF- $1 \alpha$ accumulation and transcriptional activity and was associated with decreased tumor growth [21]. Although further and detailed investigations are required, these results might represent the first steps in revealing a novel function for PKD2, namely reprogramming the energy metabolism.

\section{PKD inhibition in cancer therapy}

The emergence of PKD2 as a putative therapeutic target for cancer has encouraged the development of potent, selective, and cell-permeable small-molecule inhibitors. Several smallmolecule inhibitors such as CID755673 and analogs [166], 2,6-naphthyridine and bipyridyl and analogs [167-169], 3,5diarylazoles [170], CRT0066101 [56], pteridine [171], and CRT5 [172] were demonstrated to inhibit PKD in vitro and in intact cells. Treatment with CID755673 resulted in a significant reduction of NK cell granulation markers and cytokine release in peripheral blood mononuclear cell population [138]. This study underlines the importance of CaMKII for NK cell signaling and suggests PKD2 as a novel signaling component in activation of NK cells and cancer immunosurveillance. On the other hand, treatment with CRT0066101 was reported to efficiently block the growth of pancreatic and colon tumor xenografts in mice and was associated with G2$M$ phase arrest and induction of apoptosis [56], whereas CRT5 decreased VEGF-induced endothelial migration, proliferation, and tubulogenesis [172]. Tandon and colleagues described two new pyrazolopyrimidine pan-PKD inhibitors, namely 1-NA-PP1 and IKK-16 that potently inhibited prostate tumor cell migration and invasion [173]. Recently, a more potent PP1 derivative was synthesized showing the potential for this class of molecules as PKD inhibitors [171]. In a targeted screen of 80 chemically diverse compounds, Tandon et al. identified SD-208 that showed moderate inhibitory activity towards PKD with an IC50 of $106 \mathrm{nM}$ in vitro [171]. The (orally available) compound could inhibit prostate cancer cell survival, proliferation, and invasion in vitro and tumor growth in a xenograft model of PC3 cells [171]. PKD2 can be also indirectly targeted by using HSP90 chaperone inhibitors [88] currently under clinical evaluation such as PUH71, a water-soluble member of the purine class of HSP90 inhibitors [174] or STA-9090, a resorcinol-containing triazole molecule [175]. We have reported that HSP90dependent PKD2 stabilization results in the activation of $\mathrm{NF}-\kappa \mathrm{B}$ and its target VEGF-A, which promotes tumor cell proliferation and increased vascularization in hypoxic tumors 
[88]. All these initial steps in deciphering the intricate molecular network in which PKD2 is implicated, provide a rational basis for the design and development of new inhibitors that, alone or in combination cocktails with currently available anticancer drugs, may improve the clinical outcome. However, before any PKD-based therapies can be implemented in the clinic, the expression level and pattern of each PKD isoform has to be accurately determined so that the appropriate treatment regimen can be decided upon.

\section{Conclusion and perspectives}

There is a compelling body of evidence involving PKD2 in the regulation of multiple signaling pathways, as well as in the integration of extracellular signals that modulate cancer cell morphology, migration, proliferation, and survival (Fig. 2, Table 1, Fig. 3). Various functions of PKD2 in common human tumors were summarized in this review from the perspective of cancer hallmarks described and
Table 1 The table presents the cancer-related functions of each PKD isoform in a particular tumor type

\begin{tabular}{|c|c|c|c|c|}
\hline Isoform & $\begin{array}{l}\text { Cancer-related } \\
\text { function }\end{array}$ & Tumor type & Activation/regulation & Reference \\
\hline \multirow{7}{*}{ PKD1 } & \multirow[t]{2}{*}{ Proliferation } & Pancreatic & & {$[54]$} \\
\hline & & Prostate & MMP2/MMP9 & [177] \\
\hline & Invasion & Breast & MMP & [97] \\
\hline & \multirow[t]{3}{*}{ Tumor cell viability } & Prostate & ERK1/2, NF-кB & [87] \\
\hline & & Pancreatic & Cortactin/SSH1L & {$[55,110]$} \\
\hline & & Breast & MMP & [97] \\
\hline & \multirow[t]{3}{*}{ EMT } & Prostate & Snail & [178] \\
\hline \multirow{23}{*}{ PKD2 } & & Pancreatic & HIF-1 $1 \alpha /$ VEGF & {$[21]$} \\
\hline & & Glioma & GOLPH3/AKT & [69] \\
\hline & \multirow{4}{*}{$\begin{array}{l}\text { Proliferation } \\
\text { Invasion }\end{array}$} & Glioblastoma & Cyclin D1/p53 & [63-65] \\
\hline & & Pancreatic & MMP/Snail & {$[55,103]$} \\
\hline & & Neuroendocrine & & [176] \\
\hline & & Prostate & NF-кB/HDAC1/uPA & {$[58]$} \\
\hline & \multirow[t]{2}{*}{ Migration/motility } & Pancreatic & CIB1a & [107] \\
\hline & & Breast cancer & & {$[61]$} \\
\hline & \multirow[t]{3}{*}{ Tumor cell viability } & Myeloid leukemia & NF- $\mathrm{BB} / \mathrm{Bcr}-\mathrm{Abl}$ & [27] \\
\hline & & Prostate & ERK1/2/NF-кB & [87] \\
\hline & & Colon pancreas lung & HSP90/NF-кB & {$[88]$} \\
\hline & EMT & Hepatocellular & PI3K/GSK-3 $\beta / \beta$-catenin & {$[62]$} \\
\hline & \multirow[t]{6}{*}{ Tumor growth } & Myeloid leukemia & $\mathrm{Bcr}-\mathrm{Abl} / \mathrm{NF}-\kappa \mathrm{B}$ & {$[27]$} \\
\hline & & Glioblastoma & $\mathrm{p} 53$ & [63-65] \\
\hline & & Colorectal & & {$[56]$} \\
\hline & & Breast & & {$[60]$} \\
\hline & & Pancreas colon lung & HIF- $1 \alpha / N F-\kappa B / H S P 90$ & {$[21,88]$} \\
\hline & & Prostate & ERK1/2, NF-кB & [87] \\
\hline & \multirow[t]{2}{*}{ Secretion } & Neuroendocrine & Chromoganin A & {$[22,25]$} \\
\hline & & Pancreatic & MMP7/MMP9 & {$[55,93]$} \\
\hline & \multirow[t]{3}{*}{ Tumor angiogenesis } & Pancreatic & HIF-1 $\alpha /$ VEGF-A/BAZF & {$[21,120,121]$} \\
\hline & & Pancreatic & CIB1a/MMP9 & [107] \\
\hline & & Colon lung & 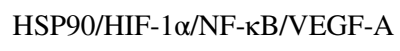 & {$[88]$} \\
\hline \multirow{5}{*}{ PKD3 } & \multirow[t]{2}{*}{ Proliferation } & Prostate & MMP2/MMP9 & [177] \\
\hline & & Breast & mTORC-S6K1 & [179] \\
\hline & \multirow[t]{2}{*}{ Tumor growth } & Prostate & Akt/ERK1-2 & {$[57]$} \\
\hline & & Breast & & {$[60]$} \\
\hline & Invasion & Prostate & NF- $\kappa$ B/HDAC1/uPA & [58] \\
\hline
\end{tabular}




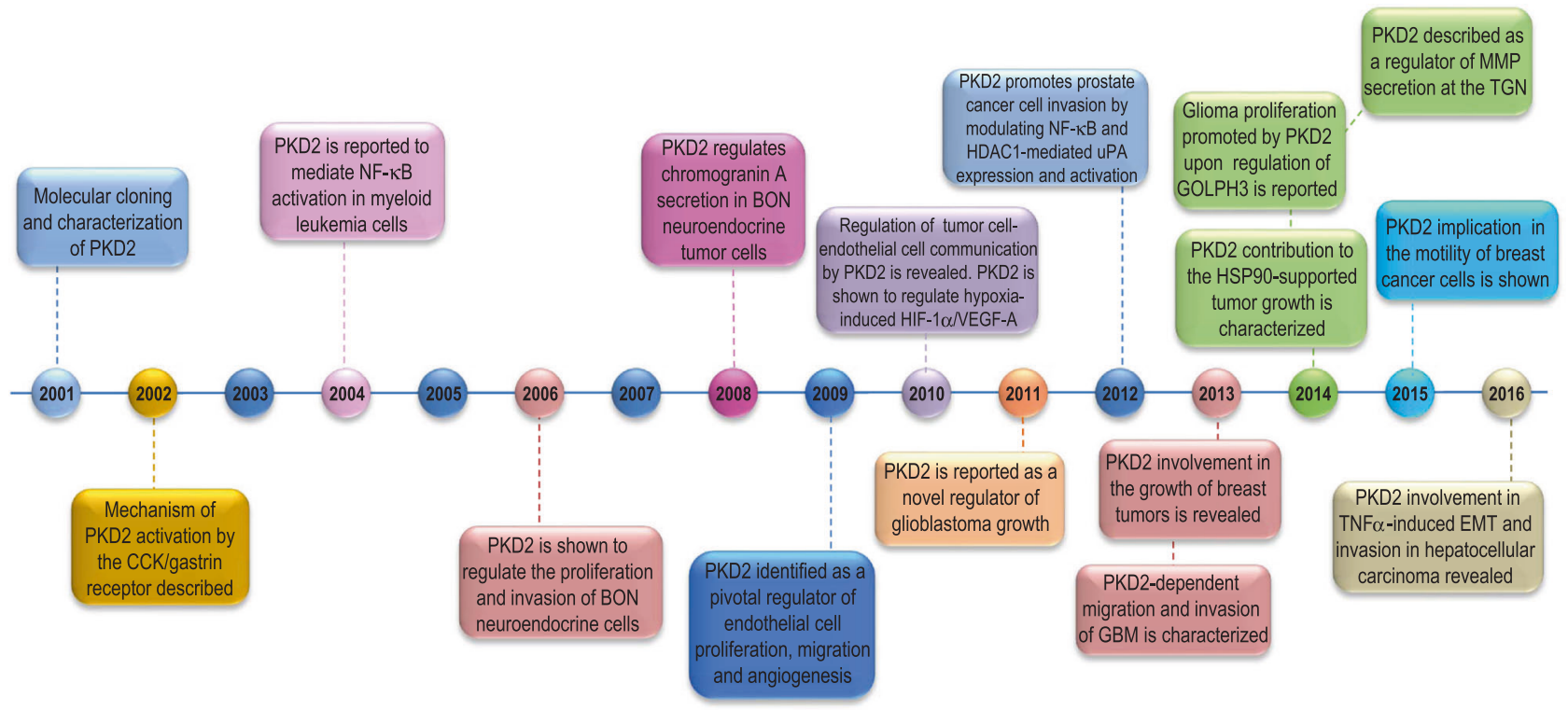

Fig. 3 The timeline presents the most important findings on the role of PKD2 in tumor progression since the molecular cloning of the kinase

revisited by Hanahan and Weinberg in years 2000 and 2011, respectively. Newly described, as well as potential functions of PKD2, not necessarily regarded as a cancer hallmark, are also presented. While multiple studies over the last 16 years identified previously unrecognized mechanisms of action for PKD2, there is still need for a better understanding of differential kinase expression, isoform-specific functions, and activation of different isoforms and molecular cross-signaling. Delineation of potential compensatory actions between various PKD isoforms in a given tumor will help to enhance the therapeutic prospects of PKDs in a successful combinatorial molecular therapy approach.

Funding This work was supported by the German Research Foundation (grants AZ.96/1-1 and AZ.96/1-3 to NA, grant SE.676/101 to TS), the German Cancer Aid (grant 109373 to TS), FP7 grant 259770 - LUNGTARGET (to JVL and TS) and IWT - Agentschap voor Innovatie door Wetenschap en Technologie (to MC).

\section{Compliance with ethical standards}

Conflict of interest The authors declare that they have no competing interests.

\section{References}

1. Manning G, Whyte DB, Martinez R, Hunter T, Sudarsanam S. The protein kinase complement of the human genome. Science 2002;298:1912-34.

2. Huse M, Kuriyan J. The conformational plasticity of protein kinases. Cell 2002;109:275-82.
3. Nolen B, Taylor S, Ghosh G. Regulation of protein kinases; controlling activity through activation segment conformation. Mol Cell. 2004;15:661-75.

4. Cohen P. Protein kinases-the major drug targets of the twentyfirst century? Nat Rev Drug Discov. 2002;1:309-15.

5. Zhang J, Yang PL, Gray NS. Targeting cancer with small molecule kinase inhibitors. Nat Rev Cancer 2009;9:28-39.

6. Matthews SA, Navarro MN, Sinclair LV, Emslie E, FeijooCarnero C, Cantrell DA. Unique functions for protein kinase D1 and protein kinase D2 in mammalian cells. Biochem J. 2010;432:153-63.

7. Valverde AM, Sinnett-Smith J, Van Lint J, Rozengurt E. Molecular cloning and characterization of protein kinase D: a target for diacylglycerol and phorbol esters with a distinctive catalytic domain. Proc Natl Acad Sci USA 1994;91:8572-76.

8. Johannes FJ, Prestle J, Dieterich S, Oberhagemann P, Link G, Pfizenmaier K. Characterization of activators and inhibitors of protein kinase C mu. Eur J Biochem. 1995;227:303-7.

9. Nishikawa K, Toker A, Johannes FJ, Songyang Z, Cantley LC. Determination of the specific substrate sequence motifs of protein kinase C isozymes. J Biol Chem. 1997;272:952-60.

10. Sturany S, Van Lint J, Muller F, Wilda M, Hameister H, Hocker $\mathrm{M}$, et al. Molecular cloning and characterization of the human protein kinase D2. A novel member of the protein kinase D family of serine threonine kinases. J Biol Chem. 2001;276:3310-18.

11. Hayashi A, Seki N, Hattori A, Kozuma S, Saito T. PKCnu, a new member of the protein kinase $\mathrm{C}$ family, composes a fourth subfamily with PKCmu. Biochim Biophys Acta 1999;1450:99-106.

12. Rykx A, De Kimpe L, Mikhalap S, et al. Protein kinase D: a family affair. FEBS Lett. 2003;546:81-86.

13. Storz P, Toker A. Protein kinase D mediates a stress-induced NFkB activation and survival pathway. EMBO J. 2003;22:109-20.

14. Iglesias T, Matthews S, Rozengurt E. Dissimilar phorbol ester binding properties of the individual cysteine-rich motifs of protein kinase D. FEBS Lett. 1998:437:19-23.

15. Auer A, von Blume J, Sturany S, von Wichert G, Van Lint J, Vandenheede $\mathrm{J}$, et al. Role of the regulatory domain of protein kinase D2 in phorbol ester binding, catalytic activity, and nucleocytoplasmic shuttling. Mol Biol Cell. 2005;9:4375-85. 
16. Sturany S, Van Lint J, Gilchrist A, Vandenheede JR, Adler G, Seufferlein T. Mechanism of activation of protein kinase D2 (PKD2) by the $\mathrm{CCK}(\mathrm{B}) / \mathrm{gastrin}$ receptor. J Biol Chem. 2002;277:29431-36.

17. von Blume J, Knippschild U, Dequiedt F, Giamas G, Beck A, Auer A, et al. Phosphorylation at Ser244 by CK1 determines nuclear localization and substrate targeting of PKD2. EMBO J. 2007;26:4619-33.

18. Cobbaut M, Derua R, Döppler H, Lou HJ, et al. Differential regulation of $\mathrm{PKD}$ isoforms in oxidative stress conditions through phosphorylation of a conserved Tyr in the $\mathrm{P}+1$ loop. Sci Rep. 2017;7:887.

19. Zugaza JL, Sinnett-Smith J, Van Lint J, Rozengurt E. Protein kinase $\mathrm{D}(\mathrm{PKD})$ activation in intact cells through a protein kinase C-dependent signal transduction pathway. EMBO J. 1996;15:6220-30.

20. Baron CL, Malhotra V. Role of diacylglycerol in PKD recruitment to the TGN and protein transport to the plasma membrane. Science 2002;295:325-28.

21. Azoitei N, Pusapati GV, Kleger A, Möller P, Küfer R, Genze F, et al. Protein kinase D2 is a crucial regulator of tumor cell endothelial cell communication in gastrointestinal tumors. Gut 2010;59:1316-30.

22. von Wichert G, Jehle PM, Hoeflich A, Koschnick S, Dralle H, Wolf E, et al. Insulin-like growth factor-I is an autocrine regulator of chromogranin A secretion and growth in human neuroendocrine tumor cells. Cancer Res. 2000;60:4573-81.

23. Bossard C, Bresson D, Polishchuk RS, Malhotra V. Dimeric PKD regulates membrane fission to form transport carriers at the TGN. J Cell Biol. 2007;179:1123-31.

24. Li J, O'Connor KL, Hellmich MR, Greeley GH Jr, Townsend $\mathrm{CM}$ Jr, Evers BM. The role of protein kinase D in neurotensin secretion mediated by protein kinase C-alpha/-delta and Rho/Rho kinase. J Biol Chem. 2004;279:28466-74.

25. von Wichert G, Edenfeld T, von Blume J, Krisp H, Krndija D, Schmid H, et al. Protein kinase D2 regulates chromogranin A secretion in human BON neuroendocrine tumour cells. Cell Signal. 2008;20:925-34.

26. Yeaman C, Ayala MI, Wright JR, Bard F, Bossard C, Ang A, et al. Protein kinase D regulates basolateral membrane protein exit from trans-Golgi network. Nat Cell Biol. 2004;6:106-12.

27. Mihailovic T, Marx M, Auer A, Van Lint J, Schmid M, Weber $\mathrm{C}$, et al. Protein kinase D2 mediates activation of nuclear factor kappaB by Bcr-Abl in Bcr-Abl+human myeloid leukemia cells. Cancer Res. 2004;64:8939-44.

28. Storz P, Döppler H, Toker A. Activation loop phosphorylation controls protein kinase D-dependent activation of nuclear factor kappaB. Mol Pharmacol. 2004;66:870-79.

29. Steiner TS, Ivison SM, Yao Y, Kifayet A. Protein kinase D1 and D2 are involved in chemokine release induced by toll-like receptors 2, 4, and 5. Cell Immunol. 2010;264:135-42.

30. Sumara G, Formentini I, Collins S, Sumara I, Windak R, Bodenmiller B, et al. Regulation of PKD by the MAPK p38delta in insulin secretion and glucose homeostasis. Cell 2009; 136:235-48.

31. Wang QJ. PKD at the crossroads of DAG and PKC signaling. Trends Pharmacol Sci. 2006;27:317-23.

32. Rey O, Yuan J, Rozengurt E. Intracellular redistribution of protein kinase D2 in response to G-protein-coupled receptor agonists. Biochem Biophys Res Commun. 2003;302:817-24.

33. Oancea E, Meyer T. Protein kinase $\mathrm{C}$ as a molecular machine for decoding calcium and diacylglycerol signals. Cell 1998;95:307-18.

34. Rey O, Sinnett-Smith J, Zhukova E, Rozengurt E. Regulated nucleocytoplasmic transport of protein kinase $D$ in response to $G$ protein-coupled receptor activation. J Biol Chem. 2001;276:49228-35.

35. Liljedahl M, Maeda Y, Colanzi A, Ayala I, Van Lint J, Malhotra V. Protein kinase D regulates the fission of cell surface destined transport carriers from the trans-Golgi network. Cell 2001;104:409-20.

36. Hausser A, Link G, Hoene M, Russo C, Selchow O, Pfizenmaier K. Phospho-specific binding of 14-3-3 proteins to phosphatidylinositol 4-kinase III beta protects from dephosphorylation and stabilizes lipid kinase activity. J Cell Sci. 2006;119:3613-21.

37. Fugmann T, Hausser A, Schöffler P, Schmid S, Pfizenmaier K, Olayioye MA. Regulation of secretory transport by protein kinase D-mediated phosphorylation of the ceramide transfer protein. J Cell Biol. 2007;17:15-22.

38. Nhek S, Ngo M, Yang X, Ng MM, Field SJ, Asara JM, et al. Regulation of oxysterol-binding protein Golgi localization through protein kinase D-mediated phosphorylation. Mol Biol Cell. 2010;21:2327-37.

39. Eiseler T, Wille C, Koehler C, Illing A, Seufferlein T. Protein kinase D2 assembles a multiprotein complex at the trans-Golgi network to regulate matrix metalloproteinase secretion. J Biol Chem. 2016;291:462-77.

40. Sidorenko SP, Law CL, Klaus SJ, Chandran KA, Takata M, Kurosaki T, et al. Protein kinase $\mathrm{C}$ mu (PKC mu) associates with the $\mathrm{B}$ cell antigen receptor complex and regulates lymphocyte signaling. Immunity 1996;5:353-63.

41. Marklund U, Lightfoot K, Cantrell D. Intracellular location and cell context-dependent function of protein kinase D. Immunity 2003;19:491-501.

42. Matthews SA, Dayalu R, Thompson LJ, Scharenberg AM. Regulation of protein kinase Cnu by the B-cell antigen receptor. J Biol Chem. 2003;278:9086-91.

43. Spitaler M, Emslie E, Wood CD, Cantrell D. Diacylglycerol and protein kinase $\mathrm{D}$ localization during $\mathrm{T}$ lymphocyte activation. Immunity 2006;24:535-46.

44. Hollenbach M, Stoll SJ, Jörgens K, Seufferlein T, Kroll J. Different regulation of physiological and tumor angiogenesis in zebrafish by protein kinase D1 (PKD1). PLoS ONE 2013;8: e68033.

45. Müller M, Schröer J, Azoitei N, Eiseler T, Bergmann W, Köhntop R, et al. A time frame permissive for protein kinase D2 activity to direct angiogenesis in mouse embryonic stem cells. Sci Rep. 2015;5:11742.

46. Geng J, Zhao Z, Kang W, Wang W, Liu G, Sun Y, et al. Hypertrophic response to angiotensin II is mediated by protein kinase D-extracellular signal-regulated kinase 5 pathway in human aortic smooth muscle cells. Biochem Biophys Res Commun. 2009;388:517-22.

47. Fielitz J, Kim MS, Shelton JM, Qi X, Hill JA, Richardson JA, et al. Requirement of protein kinase D1 for pathological cardiac remodeling. Proc Natl Acad Sci USA 2008;105:3059-63.

48. Kim Y, Phan D, van Rooij E, Wang DZ, McAnally J, Qi X, et al. The MEF2D transcription factor mediates stress-dependent cardiac remodeling in mice. J Clin Invest. 2008;118:124-32.

49. Avkiran M, Rowland AJ, Cuello F, Haworth RS. Protein kinase $\mathrm{d}$ in the cardiovascular system: emerging roles in health and disease. Circ Res. 2008;102:157-63.

50. Kleger A, Loebnitz C, Pusapati GV, Armacki M, Müller M, Tümpel S, et al. Protein kinase D2 is an essential regulator of murine myoblast differentiation. PLoS ONE 2011;6:e14599.

51. Hanahan D, Weinberg RA. The hallmarks of cancer. Cell 2000;100:57-70.

52. Hanahan D, Weinberg RA. Hallmarks of cancer: the next generation. Cell 2011;144:646-74. 
53. Pearson MA, Fabbro D. Targeting protein kinases in cancer therapy: a success? Expert Rev Anticancer Ther. 2004:4:1113-24.

54. Guha S, Rey O, Rozengurt E. Neurotensin induces protein kinase C-dependent protein kinase D activation and DNA synthesis in human pancreatic carcinoma cell line PANC-1. Cancer Res. 2002;62:1632-40.

55. Wille C, Köhler C, Armacki M, Jamali A, Gössele U, Pfizenmaier K, et al. Protein kinase D2 induces invasion of pancreatic cancer cells by regulating matrix metalloproteinases. Mol Biol Cell. 2014;25:324-36.

56. Wei N, Chu E, Wipf P, Schmitz JC. Protein kinase D as a potential chemotherapeutic target for colorectal cancer. Mol Cancer Ther. 2014;13:1130-41.

57. Chen J, Deng F, Singh SV, Wang QJ. Protein kinase D3 (PKD3) contributes to prostate cancer cell growth and survival through a PKC epsilon/PKD3 pathway downstream of Akt and ERK 1/2. Cancer Res. 2008;68:3844-53.

58. Zou Z, Zeng F, Xu W, Wang C, Ke Z, Wang QJ, et al. PKD2 and PKD3 promote prostate cancer cell invasion by modulating NF$\kappa \mathrm{B}-$ and HDAC1-mediated expression and activation of uPA. J Cell Sci. 2012;125:4800-11.

59. Shabelnik MY, Kovalevska LM, Yurchenko MY, Shlapatska LM, Rzepetsky Y, Sidorenko SP. Differential expression of PKD1 and PKD2 in gastric cancer and analysis of PKD1 and PKD2 function in the model system. Exp Oncol. 2011;33:206-11.

60. Hao Q, McKenzie R, Gan H, Tang H. Protein kinases D2 and D3 are novel growth regulators in HCC1806 triple-negative breast cancer cells. Anticancer Res. 2013;33:393-99.

61. Alpsoy A, Gündüz U. Protein kinase D2 silencing reduced motility of doxorubicin-resistant MCF7 cells. Tumour Biol. 2015;36:4417-26.

62. Zhu Y, Cheng Y, Guo Y, Chen J, Chen F, Luo R, et al. Protein kinase D2 contributes to TNF- $\alpha$-induced epithelial mesenchymal transition and invasion via the PI3K/GSK-3 $\beta / \beta$-catenin pathway in hepatocellular carcinoma. Oncotarget 2016;7:5327-41.

63. Azoitei N, Kleger A, Schoo N, Thal DR, Brunner C, Pusapati $\mathrm{GV}$, et al. Protein kinase D2 is a novel regulator of glioblastoma growth and tumor formation. Neuro Oncol. 2011;13:710-24.

64. Bernhart E, Damm S, Wintersperger A, DeVaney T, Zimmer A, Raynham T, et al. Protein kinase D2 regulates migration and invasion of U87MG glioblastoma cells in vitro. Exp Cell Res. 2013;319:2037-48.

65. Bernhart E, Damm S, Heffeter P, Wintersperger A, Asslaber M, Frank S, et al. Silencing of protein kinase D2 induces glioma cell senescence via p53-dependent and -independent pathways. Neuro Oncol. 2014;16:933-45.

66. Wang Y, Waldron RT, Dhaka A, Patel A, Riley MM, Rozengurt E, et al. The RAS effector RIN1 directly competes with RAF and is regulated by 14-3-3 proteins. Mol Cell Biol. 2002;22:916-26.

67. Wei N, Chu E, Wipf P, Schmitz JC. Protein kinase D as a potential chemotherapeutic target for colorectal cancer. Mol Cancer Ther. 2014;13:1130-41.

68. Hao Q, Wang L, Zhao ZJ, Tang H. Identification of protein kinase D2 as a pivotal regulator of endothelial cell proliferation, migration, and angiogenesis. J Biol Chem. 2009;28:799-806.

69. Zhou X, Xue P, Yang M, Shi H, Lu D, Wang Z, et al. Protein kinase D2 promotes the proliferation of glioma cells by regulating Golgi phosphoprotein 3. Cancer Lett. 2014;355:121-29.

70. Scott KL, Kabbarah O, Liang MC, Ivanova E, Anagnostou V, $\mathrm{Wu} \mathrm{J}$, et al. GOLPH3 modulates mTOR signalling and rapamycin sensitivity in cancer. Nature 2009;459:1085-90.

71. Chiu T, Rozengurt E. PKD in intestinal epithelial cells: rapid activation by phorbol esters, LPA, and angiotensin through PKC. Am J Physiol Cell Physiol. 2001;280:929-42.
72. Chiu T, Rozengurt E. CCK2 (CCK(B)/gastrin) receptor mediates rapid protein kinase $\mathrm{D}(\mathrm{PKD})$ activation through a protein kinase C-dependent pathway. FEBS Lett. 2001;489:101-6.

73. Qiang YW, Yao L, Tosato G, Rudikoff S. Insulin-like growth factor I induces migration and invasion of human multiple myeloma cells. Blood 2004;103:301-8.

74. Qin L, Zeng H, Zhao D. Requirement of protein kinase D tyrosine phosphorylation for VEGF-A165-induced angiogenesis through its interaction and regulation of phospholipase Cgamma phosphorylation. J Biol Chem. 2006;281:32550-58.

75. Wong C, Jin ZG. Protein kinase C-dependent protein kinase D activation modulates ERK signal pathway and endothelial cell proliferation by vascular endothelial growth factor. J Biol Chem. 2005;280:33262-69.

76. Lowe SW, Cepero E, Evan G. Intrinsic tumour suppression. Nature 2004:432:307-15.

77. Adams JM, Cory S. The Bcl-2 apoptotic switch in cancer development and therapy. Oncogene 2007;26:1324-37.

78. Trauzold A, Schmiedel S, Sipos B, Wermann H, Westphal S, Röder C, et al. PKCmu prevents CD95-mediated apoptosis and enhances proliferation in pancreatic tumour cells. Oncogene 2003;22:8939-47.

79. Storz P, Döppler H, Toker A. Protein kinase C delta selectively regulates protein kinase D-dependent activation of NF-kappaB in oxidative stress signaling. Mol Cell Biol. 2004;24:2614-26.

80. Storz P, Döppler H, Toker A. Protein kinase D mediates mitochondrion-to-nucleus signaling and detoxification from mitochondrial reactive oxygen species. Mol Cell Biol. 2005;25:8520-30.

81. Finkel T, Holbrook NJ. Oxidants, oxidative stress and the biology of ageing. Nature 2000;408:239-47.

82. Brunet A, Bonni A, Zigmond MJ, Lin MZ, Juo P, Hu LS, et al. Akt promotes cell survival by phosphorylating and inhibiting a Forkhead transcription factor. Cell 1999;96:857-68.

83. Brummelkamp TR, Bernards R, Agami R. A system for stable expression of short interfering RNAs in mammalian cells. Science 2002;296:550-53.

84. Ichijo H, Nishida E, Irie K, ten Dijke P, Saitoh M, Moriguchi T, et al. Induction of apoptosis by ASK1, a mammalian MAPKKK that activates SAPK/JNK and p38 signaling pathways. Science 1997;275:90-94.

85. Zhang W, Zheng S, Storz P, Min W. Protein kinase D specifically mediates apoptosis signal-regulating kinase 1-JNK signaling induced by $\mathrm{H} 2 \mathrm{O} 2$ but not tumor necrosis factor. J Biol Chem. 2005;280:19036-44.

86. Eisenberg-Lerner A, Kimchi A. DAP kinase regulates JNK signaling by binding and activating protein kinase D under oxidative stress. Cell Death Differ. 2007;14:1908-15.

87. Chen J, Giridhar KV, Zhang L, Xu S, Wang QJ. A protein kinase $\mathrm{C} /$ protein kinase $\mathrm{D}$ pathway protects $\mathrm{LNCaP}$ prostate cancer cells from phorbol ester-induced apoptosis by promoting ERK1/2 and NF-kB activities. Carcinogenesis 2011;32:1198-206.

88. Azoitei N, Diepold K, Brunner C, Rouhi A, Genze F, Becher A, et al. HSP90 supports tumor growth and angiogenesis through PRKD2 protein stabilization. Cancer Res. 2014;74:7125-36.

89. Klymkowsky MW, Savagner P. Epithelial-mesenchymal transition: a cancer researcher's conceptual friend and foe. Am J Pathol. 2009;174:1588-93.

90. Polyak K, Weinberg RA. Transitions between epithelial and mesenchymal states: acquisition of malignant and stem cell traits. Nat Rev Cancer 2009;9:265-73.

91. Yilmaz M, Christofori G. EMT, the cytoskeleton, and cancer cell invasion. Cancer Metastas Rev. 2009;28:15-33.

92. Barrallo-Gimeno A, Nieto MA. The Snail genes as inducers of cell movement and survival: implications in development and cancer. Development 2005;132:3151-61. 
93. Eiseler T, Köhler C, Nimmagadda SC, Jamali A, Funk N, Joodi G, et al. Protein kinase D1 mediates anchorage-dependent and -independent growth of tumor cells via the zinc finger transcription factor Snail1. J Biol Chem. 2012;287:32367-80.

94. Jaggi M, Rao PS, Smith DJ, Wheelock MJ, Johnson KR, Hemstreet GP, et al. E-cadherin phosphorylation by protein kinase D1 is associated with altered cellular aggregation and motility in prostate cancer. Cancer Res. 2005;65:483-92.

95. Durand N, Borges S, Storz P. Protein kinase D enzymes as regulators of EMT and cancer cell invasion. J Clin Med. 2016;5: pii: E20.

96. Kessenbrock K, Plaks V, Werb Z. Matrix metalloproteinases: regulators of the tumor microenvironment. Cell 2010;141:52-67.

97. Soria G, Ofri-Shahak M, Haas I, Yaal-Hahoshen N, Leider-Trejo $\mathrm{L}$, Leibovich-Rivkin $\mathrm{T}$, et al. Inflammatory mediators in breast cancer: coordinated expression of TNF $\alpha$ \& IL-1 $\beta$ with CCL2 \& CCL5 and effects on epithelial-to-mesenchymal transition. BMC Cancer 2011;11:130.

98. Yan C, Grimm WA, Garner WL, Qin L, Travis T, Tan N, et al. Epithelial to mesenchymal transition in human skin wound healing is induced by tumor necrosis factor-alpha through bone morphogenic protein-2. Am J Pathol. 2010;176:2247-58.

99. Van Lint J, Rykx A, Maeda Y, Vantus T, Sturany S, Malhotra V, et al. Protein kinase D: an intracellular traffic regulator on the move. Trends Cell Biol. 2002;12:193-200.

100. Eiseler T, Döppler H, Yan IK, Goodison S, Storz P. Protein kinase D1 regulates matrix metalloproteinase expression and inhibits breast cancer cell invasion. Breast Cancer Res. 2009;11: R13.

101. Borges S, Perez EA, Thompson EA, Radisky DC, Geiger XJ, Storz P. Effective targeting of estrogen receptor-negative breast cancers with the protein kinase D inhibitor CRT0066101. Mol Cancer Ther. 2015;14:1306-16.

102. Liu ZC, Chen XH, Song HX, Wang HS, Zhang G, Wang H, et al. Snail regulated by PKC/GSK-3 $\beta$ pathway is crucial for EGF-induced epithelial-mesenchymal transition (EMT) of cancer cells. Cell Tissue Res. 2014;358:491-502.

103. Wille C, Seufferlein T, Eiseler T. Protein kinase D family kinases: roads start to segregate. Bioarchitecture 2014;4:111-15.

104. Bergers G, Brekken R, McMahon G, Vu TH, Itoh T, Tamaki K, et al. Matrix metalloproteinase-9 triggers the angiogenic switch during carcinogenesis. Nat Cell Biol. 2000;2:737-44.

105. Bergers G, Benjamin LE. Tumorigenesis and the angiogenic switch. Nat Rev Cancer 2003;3:401-10.

106. Yoo J, Rodriguez Perez CE, Nie W, Sinnett-Smith J, Rozengurt E. Protein kinase D1 mediates synergistic MMP-3 expression induced by TNF- $\alpha$ and bradykinin in human colonic myofibroblasts. Biochem Biophys Res Commun. 2011;413:30-35.

107. Armacki M, Joodi G, Nimmagadda SC, de Kimpe L, Pusapati $\mathrm{GV}$, Vandoninck S, et al. A novel splice variant of calcium and integrin-binding protein 1 mediates protein kinase D2-stimulated tumour growth by regulating angiogenesis. Oncogene 2014;33:1167-80.

108. Janssens K, De Kimpe L, Balsamo M, Vandoninck S, Vandenheede JR, Gertler F, et al. Characterization of EVL-I as a protein kinase D substrate. Cell Signal. 2009;21:282-92.

109. Egeblad M, Werb Z. New functions for the matrix metalloproteinases in cancer progression. Nat Rev Cancer 2002;2:161-74.

110. Eiseler T, Hausser A, De Kimpe L, Van Lint J, Pfizenmaier K. Protein kinase D controls actin polymerization and cell motility through phosphorylation of cortactin. J Biol Chem. 2010;285:18672-83.

111. Baeriswyl V, Christofori G. The angiogenic switch in carcinogenesis. Semin Cancer Biol. 2009;19:329-37.

112. Mac Gabhann F, Popel AS. Systems biology of vascular endothelial growth factors. Microcirculation 2008;15:715-38.
113. Sipos B, Weber D, Ungefroren H, Kalthoff H, Zühlsdorff A, Luther $\mathrm{C}$, et al. Vascular endothelial growth factor mediated angiogenic potential of pancreatic ductal carcinomas enhanced by hypoxia: an in vitro and in vivo study. Int $\mathrm{J}$ Cancer 2002;102:592-600.

114. Ijichi S, Kusaka T, Isobe $\mathrm{K}$, Islam F, Okubo K, Okada H, et al. Quantification of cerebral hemoglobin as a function of oxygenation using near-infrared time-resolved spectroscopy in a piglet model of hypoxia. J Biomed Opt. 2005;10:024026.

115. Barbara M, Pilar de la P, Feda A, Abdel Kareem A. The role of hypoxia in cancer progression, angiogenesis, metastasis, and resistance to therapy. Hypoxia (Auckl) 2015;3:83-92.

116. Chouaib S, Messai Y, Sophie C, Bernard E, Meriem H. Hypoxia promotes tumor growth in linking angiogenesis to immune escape. Front Immunol. 2012;3:21.

117. Eales KL, Hollinshead KER, Tennant DA. Hypoxia and metabolic adaptation of cancer cells. Oncogenesis 2016;5:e190.

118. Young TA, Wang H, Munk S, Hammoudi DS, Young DS, Mandelcorn MS, et al. Vascular endothelial growth factor expression and secretion by retinal pigment epithelial cells in high glucose and hypoxia is protein kinase C-dependent. Exp Eye Res. 2005;80:651-62.

119. Dequiedt F, Van Lint J, Lecomte E, Van Duppen V, Seufferlein T, Vandenheede JR, et al. Phosphorylation of histone deacetylase 7 by protein kinase D mediates T cell receptor-induced Nur77 expression and apoptosis. J Exp Med. 2005;201:793-804.

120. Zeng H, Qin L, Zhao D, Tan X, Manseau EJ, Van Hoang M, et al. Orphan nuclear receptor TR3/Nur77 regulates VEGF-Ainduced angiogenesis through its transcriptional activity. J Exp Med. 2006;203:719-29.

121. Miwa D, Sakaue T, Inoue H, Takemori N, Kurokawa M, Fukuda $\mathrm{S}$, et al. Protein kinase D2 and heat shock protein 90 beta are required for BCL6-associated zinc finger protein mRNA stabilization induced by vascular endothelial growth factor-A. Angiogenesis 2013;16:675-88.

122. Dou GR, Wang YC, Hu XB, Hou LH, Wang CM, Xu JF, et al. RBP-J, the transcription factor downstream of Notch receptors, is essential for the maintenance of vascular homeostasis in adult mice. FASEB J. 2008;22:1606-17.

123. Hellström M, Phng LK, Hofmann JJ, Wallgard E, Coultas L, Lindblom P, et al. Dll4 signalling through Notch1 regulates formation of tip cells during angiogenesis. Nature 2007;445:776-80.

124. Jakobsson L, Franco CA, Bentley K, Collins RT, Ponsioen B, Aspalter IM, et al. Endothelial cells dynamically compete for the tip cell position during angiogenic sprouting. Nat Cell Biol. 2010;12:943-53.

125. Benedito R, Roca C, Sörensen I, Adams S, Gossler A, Fruttiger $\mathrm{M}$, et al. The notch ligands Dl14 and Jagged1 have opposing effects on angiogenesis. Cell 2009;137:1124-35.

126. Isaacs JS, Jung YJ, Mimnaugh EG, Martinez A, Cuttitta F, Neckers LM. Hsp90 regulates a von Hippel Lindau-independent hypoxia-inducible factor-1 alpha-degradative pathway. J Biol Chem. 2002;277:29936-44.

127. Neckers L, Neckers K. Heat-shock protein 90 inhibitors as novel cancer chemotherapeutic agents. Expert Opin Emerg Drugs 2002;7:277-88.

128. Minet E, Mottet D, Michel G, Roland I, Raes M, Remacle J, et al. Hypoxia-induced activation of HIF-1: role of HIF-1alphaHsp90 interaction. FEBS Lett. 1999;460:251-56.

129. Choi JW, Park SC, Kang GH, Liu JO, Youn HD. Nur77 activated by hypoxia-inducible factor-1alpha overproduces proopiomelanocortin in von Hippel-Lindau-mutated renal cell carcinoma. Cancer Res. 2004;64:35-39.

130. Yoo YG, Yeo MG, Kim DK, Park H, Lee MO. Novel function of orphan nuclear receptor Nur77 in stabilizing hypoxia-inducible factor-1alpha. J Biol Chem. 2004;279:53365-73. 
131. Culver C, Sundqvist A, Mudie S, Melvin A, Xirodimas D, Rocha S. Mechanism of hypoxia-induced NF-kappaB. Mol Cell Biol. 2010;30:4901-21.

132. Pfeifhofer $\mathrm{C}$, Gruber $\mathrm{T}$, Letschka $\mathrm{T}$, Thuille $\mathrm{N}$, Lutz-Nicoladoni C, Hermann-Kleiter N, et al. Defective IgG2a/2b class switching in PKC alpha-/- mice. J Immunol. 2006;176:6004-11.

133. Pfeifhofer C, Kofler K, Gruber T, Tabrizi NG, Lutz C, Maly K, et al. Protein kinase $\mathrm{C}$ theta affects $\mathrm{Ca} 2+$ mobilization and NFAT cell activation in primary mouse $\mathrm{T}$ cells. $\mathrm{J}$ Exp Med. 2003;197:1525-35.

134. Gruber T, Hermann-Kleiter N, Pfeifhofer-Obermair C, LutzNicoladoni C, Thuille N, Letschka T, et al. PKC theta cooperates with $\mathrm{PKC}$ alpha in alloimmune responses of T cells in vivo. Mol Immunol. 2009;46:2071-79.

135. Zheng H, Qian J, Baker DP, Fuchs SY. Tyrosine phosphorylation of protein kinase D2 mediates ligand-inducible elimination of the Type 1 interferon receptor. $\mathrm{J}$ Biol Chem. 2011;286:35733-41.

136. Chen J, Feng Y, Lu L, Wang H, Dai L, Li Y, et al. Interferon- $\gamma$ induced PD-L1 surface expression on human oral squamous carcinoma via PKD2 signal pathway. Immunobiology 2012;217:385-93.

137. Vivier E, Tomasello E, Baratin M, Walzer T, Ugolini S. Functions of natural killer cells. Nat Immunol. 2008;9:503-10.

138. Bryceson YT, Ljunggren HG, Long EO. Minimal requirement for induction of natural cytotoxicity and intersection of activation signals by inhibitory receptors. Blood 2009;114:2657-66.

139. Scheiter M, Bulitta B, van Ham M, Klawonn F, König S, Jänsch L. Protein kinase inhibitors CK59 and CID755673 alter primary human NK cell effector functions. Front Immunol. 2013;4:66.

140. Sharlow ER, Giridhar KV, LaValle CR, Chen J, Leimgruber S, Barrett R, et al. Potent and selective disruption of protein kinase D functionality by a benzoxoloazepinolone. J Biol Chem. 2008;283:33516-26.

141. Patel S, Ngounou Wetie AG, Darie CC, Clarkson BD. Cancer secretomes and their place in supplementing other hallmarks of cancer. Adv Exp Med Biol. 2014;806:409-42.

142. Malhotra V, Campelo F. PKD regulates membrane fission to generate TGN to cell surface transport carriers. Cold Spring Harb Perspect Biol. 2011;3:pii: a005280.

143. Diaz Anel AM, Malhotra V. PKCeta is required for beta1gamma2/beta3gamma2- and PKD-mediated transport to the cell surface and the organization of the Golgi apparatus. J Cell Biol. 2005;169:83-91.

144. Goginashvili A, Zhang Z, Erbs E, Spiegelhalter C, Kessler P, Mihlan $\mathrm{M}$, et al. Insulin granules. Insulin secretory granules control autophagy in pancreatic $\beta$ cells. Science 2015;347:878-82.

145. Ochi N, Tanasanvimon S, Matsuo Y, Tong Z, Sung B, Aggarwal $\mathrm{BB}$, et al. Protein kinase D1 promotes anchorage-independent growth, invasion, and angiogenesis by human pancreatic cancer cells. J Cell Physiol. 2011;226:1074-81.

146. Steiner TS, Ivison SM, Yao Y, Kifayet A. Protein kinase D1 and D2 are involved in chemokine release induced by toll-like receptors 2, 4, and 5. Cell Immunol. 2010;264:135-42.

147. Hao Q, Wang L, Tang H. Vascular endothelial growth factor induces protein kinase $\mathrm{D}$-dependent production of proinflammatory cytokines in endothelial cells. Am J Physiol Cell Physiol. 2009;296:821-27.

148. Fanelli MF, Chinen LT Sr, Begnami MD, Costa WL Jr, Fregnami JH, et al. The influence of CD44v6, TGF- $\alpha$, COX-2, MMP7 , and MMP-9 on clinical evolution of patients with gastric cancer. J Clin Oncol. 2011;29:21.

149. Egeblad M, Werb Z. New functions for the matrix metalloproteinases in cancer progression. Nat Rev Cancer 2002;2:161-74.
150. LaValle CR, Zhang L, Xu S, Eiseman JL, Wang QJ. Inducible silencing of protein kinase D3 inhibits secretion of tumorpromoting factors in prostate cancer. Mol Cancer Ther. 2012;11:1389-99.

151. Fugmann $\mathrm{T}$, et al Regulation of secretory transport by protein kinase D-mediated phosphorylation of the ceramide transfer protein. J Cell Biol. 2011;178:15-22.

152. Hausser A, et al Protein kinase D regulates vesicular transport by phosphorylating and activating phosphatidylinositol-4 kinase IIIbeta at the Golgi complex. Nat Cell Biol. 2005;7:880-86.

153. Pusapati GV, et al Role of the second cysteine-rich domain and Pro275 in protein kinase D2 interaction with ADP-ribosylation factor 1, trans-Golgi network recruitment, and protein transport. Mol Biol Cell. 2010;21:1011-22.

154. Donaldson JG, Honda A. Localization and function of Arf family GTPases. Biochem Soc Trans. 2005;33:639-42.

155. Bonifacino JS, Glick BS. The mechanisms of vesicle budding and fusion. Cell 2004;116:153-66.

156. D'Souza-Schorey C, Chavrier P. ARF proteins: roles in membrane traffic and beyond. Nat Rev Mol Cell Biol. 2006;7:347-58.

157. Koch, et al. ADP ribosylation factor-dependent phospholipase $\mathrm{D} 2$ activation is required for agonist-induced mu-opioid receptor endocytosis. J Biol Chem. 2003;278:9979-85.

158. Mitchell, et al. ADP-ribosylation factor-dependent phospholipase D activation by the M3 muscarinic receptor. J Biol Chem. 2003;278:33818-30.

159. Aikawa, et al ARF6 regulates a plasma membrane pool of phosphatidylinositol $(4,5)$ bisphosphate required for regulated endocytosis. J Cell Biol. 2003;16:647-59.

160. Aicart-Ramos C, He SD, Land M, Rubin CS. A novel conserved domain mediates dimerization of protein kinase $\mathrm{D}$ (PKD) isoforms: dimerization is essential for PKD-dependent regulation of secretion and innate immunity. J Biol Chem. 2016;291:23516-31.

161. McDonald PC, Chafe SC, Dedhar S. Overcoming hypoxiamediated tumor progression: combinatorial approaches targeting $\mathrm{pH}$ regulation, angiogenesis and immune dysfunction. Front Cell Dev Biol. 2016;4:27-32.

162. Marchiq I, Pouysségur J. Hypoxia, cancer metabolism and the therapeutic benefit of targeting lactate/ $\mathrm{H}(+)$ symporters. J Mol Med. (Berl) 2016;94:155-71.

163. Pouysségur J, Dayan F, Mazure NM. Hypoxia signalling in cancer and approaches to enforce tumour regression. Nature 2006;441:437-43.

164. Semenza GL. Defining the role of hypoxia-inducible factor 1 in cancer biology and therapeutics. Oncogene 2010;29:625-34.

165. Kroemer G, Pouyssegur J. Tumor cell metabolism: cancer's Achilles' heel. Cancer Cell. 2008;13:472-82.

166. George KM, Frantz MC, Bravo-Altamirano K, Lavalle CR, Tandon M, Leimgruber S, et al. Design, synthesis, and biological evaluation of PKD inhibitors. Pharmaceutics 2011;3:186-28.

167. Monovich L, Vega RB, Meredith E, Miranda K, Rao C, Capparelli $\mathrm{M}$, et al. A novel kinase inhibitor establishes a predominant role for protein kinase D as a cardiac class IIa histone deacetylase kinase. FEBS Lett. 2010;584:631-37.

168. Meredith EL, Beattie K, Burgis R, Capparelli M, Chapo J, Dipietro L, et al. Identiication of potent and selective amidobipyridyl inhibitors of protein kinase D. J Med Chem. 2010;53:5422-38.

169. Meredith EL, Ardayfio O, Beattie K, Dobler MR, Enyedy I, Gaul $\mathrm{C}$, et al. Identification of orally available naphthyridine protein kinase D inhibitors. J Med Chem. 2010;53:5400-21.

170. Gamber GG, Meredith E, Zhu Q, Yan W, Rao C, Capparelli M, et al. 3,5-diarylazoles as novel and selective inhibitors of protein kinase D. Bioorg Med Chem Lett. 2011;21:1447-51.

171. Tandon M, Salamoun JM, Carder EJ, Farber E, Xu S, Deng F, et al. SD-208, a novel protein kinase D inhibitor, blocks prostate 
cancer cell proliferation and tumor growth in vivo by inducing G2/M cell cycle arrest. PLoS ONE 2015;10:e0119346.

172. Evans IM, Bagherzadeh A, Charles M, Raynham T, Ireson C, Boakes A, et al. Characterization of the biological effects of a novel protein kinase D inhibitor in endothelial cells. Biochem J. 2010;429:565-72.

173. Tandon M, Johnson J, Li Z, Xu S, Wipf P, Wang QJ. New pyrazolopyrimidine inhibitors of protein kinase $\mathrm{d}$ as potent anticancer agents for prostate cancer cells. PLoS ONE 2013;8:e75601.

174. Moulick K, Ahn JH, Zong H, Rodina A, Cerchietti L, Gomes DaGama EM, et al. Affinity-based proteomics reveal cancerspecific networks coordinated by Hsp90. Nat Chem Biol. 2011;7:818-26.

175. Wang Y, Trepel JB, Neckers LM, Giaccone G. STA-9090, a small molecule HSP90 inhibitor for the potential treatment of cancer. Curr Opin Investig Drugs 2010;11:1466-76.
176. Jackson LN, Li J, Chen LA, Townsend CM, Evers BM. Overexpression of wild-type PKD2 leads to increased proliferation and invasion of BON endocrine cells. Biochem Biophys Res Commun. 2006;348:945-49.

177. Biswas MH, Du C, Zhang C, Straubhaar J, Languino LR, Balaji KC. Protein kinase D1 inhibits cell proliferation through matrix metalloproteinase-2 and matrix metalloproteinase-9 secretion in prostate cancer. Cancer Res. 2010;70:2095-100.

178. Du C, Zhang C, Hassan S, Biswas MH, Balaji KC. Protein kinase D1 suppresses epithelial-to-mesenchymal transition through phosphorylation of snail. Cancer Res. 2010;70:7810-19.

179. Huck B, Duss S, Hausser A, Olayioye MA. Elevated protein kinase D3 (PKD3) expression supports proliferation of triplenegative breast cancer cells and contributes to mTORC1-S6K1 pathway activation. J Biol Chem. 2014;289:3138-47. 